handle. The series of publications started early in the War to present authentic information on the peoples, geography, history and other features of war areas, entitled "War Background Studies", was completed during the year.

Among the outstanding publications of the year were C. G. Abbot's "Weather Predetermined by Solar Variation" in the Smithsonian Miscellaneous Collections; "Summary of the Collections of Amphibians made in Mexico under the Walter Rathbone Bacon Travelling Scholarship" by E. H. Taylor and H. M. Smith ; and "Review of the Spider Monkeys" by R. Kellogg and E. A. Goldman in the Proceedings of the National Museum, and "Houses and House Use of the Sierra Tarascans" by R. L. Beals, P. Carrasco and T. McCorkle, the first publication of the Institute of Social Anthropology.

Accessions to the Library totalled 4,844, bringing the total holdings to 918,460 . A considerable number of valuable old works, some dating from the seven. teenth and eighteenth centuries, were acquired by purchase during the year. The regular sending of consignments to the liberated countries of scientific publications had not been resumed by the International Exchange Service, and accumulations for France, Italy and Belgium were forwarded to the Office of War Information, and those for Sweden, Palestine and Egypt through the United States dispatch agent in New York.

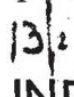

\section{INDUSTRIAL DEVELOPMENT IN EAST AFRICA}

$\mathrm{T}$ HE sedond annual report of the East African Industr Research Board deals with activities for thayeg ending December 31, 1944, and stresses the $\mathrm{e}_{\mathrm{a}} \mathrm{fd}$ (1) competent survey of the industrial opprtunities of the country and for planning for the Dorterly and rapid realization. The Board is conderned that its present war-time improvisations should be developed into a strong peace-time organisation, staffed with specialists in industrial science, economics and technology. Industrial research must now be judged by its contributions to the establishment of permanent competitive industry, and this means concentration on a smaller number of problems.

During 1944, the Industrial Management Board completed the installation at Nairobi of the old oilpressing equipment removed from Merca in Somalia, and when production of cotton-seed oil started, the Industrial Research Board was called upon to assist in establishing processes and controlling products. Investigations were also started to assist in the improvement of locally produced soap, while a process has been developed for the preparation of motor fuel and other petroleum products by a method based on vapour-phase cracking of the vegetable oils contained in seeds. The seeds are heated to about $500^{\circ}-550^{\circ} \mathrm{C}$., when the oils are vaporized and partly cracked, the vapours passing to a cracking tube at $500^{\circ}-650^{\circ}$ C. at a pressure of about $100 \mathrm{lb}$. per sq. in. Fuel oils are recovered from the issuing gases by condensation and refined by conventional methods, a yield of about 26 gallons of motor spirit being obtained on the small plant per ton of cotton seed.

Investigations were also carried out to determine the physical constants of fibre board manufactured at Thika factory, Kenya, including expansion and expansion under changes of relative humidity, as well as on the water-proofing of soft fibre boards, surface treatment with a paraffin wax emulsion giving a water-resistant surface. Some attention has been given to the sizing of fibre boards to render them resistant to disintegration when wet, and some success was obtained by incorporating rubber latex, especially Euphorbia latex, in forming the board. The treatment of the boards to render them fireresistant, and methods of extracting pyrethrum flowers, are other problems that have received attention. A pilot plant provided enough 4 per cent extract to meet essential needs. A new method involving extraction with the minimum amount of a non-volatile kerosene was developed, using a counter. current system and a rotary expeller; with this, some 2,500 gallons of 4 per cent extract were made available from some sixty tons of pyrethrum powder in military stores that would otherwise rapidly have become valueless. No substitutes examined gave promise of replacing pyrethrum by other insecticides not in similar demand for war purposes.

Vegetable fuels, the fire-proofing of fabrics and other materials, the protection of timber from insect damage, phosphatic fertilizers and ceramics are among other subjects engaging the attention of the Board, the latter having become the most important single item in the Board's research programme. Striking results have been obtained in making roofing tiles by incorporating certain vegetable fibres in the bodies used.

Included in this report are the reports of the Uganda Industrial Committee and of the Tanganyika Industrial Committee. The former committee functions both as a local agent and liaison for the East African Industrial Research Board, and as the body responsible to the Uganda Government for various industrial operations and undertakings. The handspinning and weaving centre at Kampala was continued until the latter part of the year, and construction of a pottery to provide essential articles to meet local demand was completed in February 1944, including a Chinese-type kiln. Under the Tanganyika Industrial Committee, a successor to the East African Substitutes Committee, research was carried out at Totaquina factory on the effect of fineness of grinding on efficiency of extraction, the course of the process of extraction of the alkaloids from the aqueous phase by oil, and the possibility of increasing the efficiency of extraction by adding amyl alcohol to the diesolene. At the Hone factory, experimental work on the pro. duction of different types of abrasive articles continued, and the first successful high-speed abrasive wheel to be made in East Africa was produced during the year.

\section{AERIAL RECONNAISSANCE IN FORESTRY}

$T$ HE aeroplane has been used to assist in forest fire protetion fifsolne years, and its use was brought ang (fandald of efficiency in Canada before th-First World War. It had also been more or If thetative y used by the Forest Department in Indid as an aid to describing the growing stock of forest areas for which working plans were under preparation. In the minds of many forest officers of experience, having regard to the considerable expense involved, the possibilities of its practical use were not regarded with any great enthusiasm. 
The subject was referred to at the Sixth Sylvicultural Conference held in India in 1945. As is well known, a great deal of very accurate aerial photography was carried out in India and Burma during the Second World War by both the R.A.F. and the American Air Force. Mr. A. L. Griffith, of the Central Sylvicultural Forest Research Institute, dis. cusses this matter in the Indian Forester (72, No. 5, May 1946. Civil and Military Gazette, Ltd., Lahore), stating that full use should be made of the work the air forces have done so far as Indian forests are concerned. As he remarks, many areas are difficult to get to and difficult to traverse on the ground, while others in addition are very unhealthy. Such areas are often not worth the time, labour and expense of a ground party. On the other hand, it has always been considered that accurate air surveys are expensive, difficult to organise and require a specially trained staff. The average forest officer has, therefore, hesitated to propose the use of an aeroplane for the purpose.

Mr. Griffith had occasion to make a fairly extensive tour of the Thar Desert of Sind. This is the southwestern part of the Great Indian Desert and is some 10,000 square miles in area. It is bounded in the west by the Nara River, in the south by the Rann of Cutch, and in the north and east by other parts of the desert. It was desired to obtain information on the subject of the desert scrub growth in connexion with the Development of Sind plans. Some two hundred miles were travelled by camel, and the party saw a fair amount of the westerly edge of the area from Naukot in the south to Chhor in the north, penetrating some 30-40 miles into the desert. It was necessary to see the more southerly and easterly parts of the area, mainly towards Nagar Parkar on the edge of the Rann of Cutch, from which the general sand drift starts. This was done in a chartered Gipsy Moth aeroplane. Mr. Griffith found that he could take perfectly serviceable air photographs with an ordinary camera, though he had never tried to take an air photograph before. The experience gained and photographs have shown the value of this type of reconnaissance to the forest officer, alike for working plan purposes, erosion schemes, reconnaissance of new forest areas, and so forth.

$-16$

\section{PROPERTIES OF THE EARTH'S CRUSTAL LAYERS}

DENO GUTEx Bfir has examined this problem 3 in the ligh sua suggestion made by Zoeppritz in 1912 the 194 atiges with distance in amplitudes of for and Sual earthquakes recorded at of this sace have been used (Amer. J. Sci., 243, A, Daly Vuitume, 1945, pp. 285-312).

Gutenberg finds that the Mohorovičic discontinuity is at a depth of about $35-40 \mathrm{~km}$. in the coastal areas of southern California, but deeper under mountain ranges. The velocity of $P n$ below it is close to $8.0 \mathrm{~km}$. $/ \mathrm{sec}$. At first, the velocities of both $P$ and $S$ increase with depth, probably at a rate similar to that in the upper layers, but the rate of increase falls off rapidly with increasing depth, resulting in a rapid decrease of the amplitudes of $P n$ and $S n$ with distance beyond $\Delta=200 \mathrm{~km}$. Amplitudes of $P n$ and similarly of $S n$ in intermediate shocks without appreciable surface waves on records of shocks originating at various depths within a radius of about $2,000 \mathrm{~km}$. from Huancayo, Peru, and recorded at the station there, confirm the previous results of Gutenberg and Richter (1939) concerning the relationship between the epicentral distances at which the amplitudes of $P n$ are very small, and the focal depth of the shocks.

These findings can be explained on the assumption that at a depth of about $80 \mathrm{~km}$. the melting point of the material is reached. Immediately above that critical depth, the effect of temperature on the bulk modulus and on the coefficient of rigidity may approach or even surpass the effect of pressure. At the critical depth itself, there may be a slight sudden decrease of the wave velocity. Experimental data (Birch et al., "Handbook of Physical Constants", Geol. Soc. Amer. Spec. Papers, No. 36 (1942), pp. 15, 28 and 59) are insufficient to decide which decrease is larger at the melting point, that of the elastic constants or that of the density. At greater depth, the effect of the temperature on the bulk modulus and the coefficient of rigidity becomes more and more insignificant. Whereas above the critical depth, a minimum stress of the order of $10^{\circ}$ dynes $/ \mathrm{cm}^{2}$ (the strength) is required to start plastic flow, below this depth the strength is much smaller, and the plastic flow is controlled mainly by the plasticity of the material.

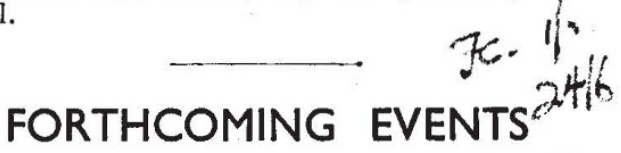

(Meetings marked with an asterisk * are open to the public)

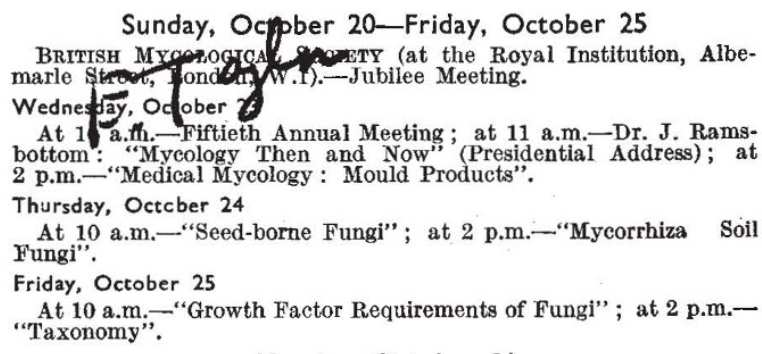

Monday, October 21

CHEMICAL SOCIETY (joint meeting with the ROYAL INSTITUTE OF CHEMISTRY, the SOCIETY OF CHEMIOAL INDUSTRY, and the BUREAU OF ABSTRACTS, at the London School of Hygiene and Tropical Medicine "A. New Notation for Organic Chemistry".

Tuesday, October 22

INSTITUTE OF PHYSICS, ELFOTRONICS GROUP (at the Royal Society, Burlington House, Piccadilly, London, W.1), at 5.30 p.m.-Prof. R. E. Peierls: "Fundamental Particles".

Wednesday, October 23

RESEAROH DEFENCE Society (at Manson House, Royal Society of Tropical Medicine and Hygiene, 26 Portland Place, London, W.1), at 3.15 p.m.-Annual General Meeting. Prof. N. Hamilton Fairley : "War-time Research in Malaria and other Tropical Diseases

INSTITUTION OF POST OFFICE ELBCTRICAL ENGINEERS (at Faraday INSTITUTION OF POST OFFICE ELECTRICAL ENGINEERS (at Faraday
Building, 9th Floor, South Block, Knightrider Street, London, E.C.4), Building, 9th Floor, South Block, Knightrider Street, London, E.C.4),
at 5 p.m.-Mr. J. Eccles : "Buikdings for Telecommunications-Some at 5 p.m.-Mr. J. Eccles :

ROYAL AERONAUTICAL SOCIETY (at the Institution of Civil Engineers, Great George Street, London, S.W.1), at 6 p.m.--Mr. H. F. Pritchard "The Problems of Blind Landing".

Royal Statistical Society, Birmingham and District Group OF THE INDUSTRIAL APPLICATIONS SECTION (in the Chamber of Commerce, 95 New Street, Birmingham 2), at 6.30 p.m.-Mr. A. S. Wharton: "Market Research".

SOCIETY OF CHEMICAL INDUSTRY, FOOD GROUP (at the Chemical Society, Burlington House, Piccadilly, London, W.1), at 6.30 p.m.Discussion on "Sweet Confeetionery" (Mr. D. W. Grover: "Th Keeping Properties of Confectionery as Influenced by its Water Vapour Pressure"; Mr. H. F. Bamford and Mr. H. M. Mason : "Estimation of the Fineness of Grinding of Chocolate"). 